skull, and rectum, are illustrated by appropriate woodcuts; and the article concludes with a very complete bibliography of cancer.

We have already expressed a general opinion on the merits of this able essay. In a department of medical science which requires for its cultivation great assiduity, sound judgment, and quick apprehension, it is encouraging to find that a labourer has appeared, who may one day prove himself worthy to follow the steps of a Meckel, a Cruveilhier, or a Carswell.

A Few Facts relative to Vaccination. By Henry W.
Livetr, Surgeon. Simpkin \& Co. London. 8vo.
Pp. 19.

Trrs little tract, addressed to the guardians of the poor of the Wells union, has been written for the purpose of promoting the practice of vaccination. It contains a number of facts arranged in a popular form, which, though well known to the profession, require to be promulgated amongst the public, and impressed on the minds of all those who can in any way influence the uneducated classes of society. We, therefore, feel indebted to Mr. Livett for his laudable undertaking, and would express a hope that medical men, generally, will endeavour, either through similar publications, or by popular discourses, to remove the prejudices which still exist against vaccination. Much may be done by well-combined efforts of this kind on the part of intelligent medical men. Orations are daily delivered on the "corn-laws," on "total abstinence," on " the drama," in a word, on almost every species of "predicable" things; surely one of the greatest boons which science has conferred on mankind will not languish for lack of advocates.

\section{THE MAYOR OF NEWCASTLE AND THE} ANATOMY AC'.

TO THE EDITORS OF THE PROVINCIAL MEDICAL AND SURGICAL JOURNAL.

Genteemen,-We think it right to make known, through the medium of your widely-circulated Journal, to the profession and to the public, the following circumstances which occurred in this town on the $19 \mathrm{th}$ instant.

In the evening of the above-named day the body of an clderly female pauper, who died without any relatives, was removed to the medical school for anatomical purposes, with the concurrence of the proper authorities. About an hour and a haif afterwards three of the lecturers being in front of the school at the time, a party of Irish people, accompanied by the mayor and several policemen, suddenly rushed into the yard of the institution, without giving any notice, the mayor crying out to the police, " if there's any of these men here stop them-don't let any one go out." On advancing, and perceiving the lecturers, he exclaimed with vehemence. "You've got a body here-open these doors, or I'll break them in for you directly." "Well, Mr. Mayor, allow me to explain," began one of the lecturers." "I won't hear it," interrupted the mayor; "I won't hear any thing in private, it shall all be made public, and I'll have every body connected with it punished severely."

No obstacle whatever was put in the way of his worship - the door was opened, when the whole party entered the dissecting-room, and proceeded, at the command of the mayor, to remove the body from the leaden trough, in which it was being heated preparatory to injection, into the coffin. Whilst this was going on, one of the lecturers begged the major, whio was all the while in a state of high excitement, to recollect that the body had been legally obtained.
To which he replied, "Never mind, I don't care for that ! it shan $t$ be done here! I won't allow of it in this town!you'll be getting live ones next!! I'll have it thoroughly sifted into, and no body connected with it shall have ha'porth o' lenity." 'The mayor was assured that no hindrance would be offered to his proceedings, but that, on the contrary, every facility should be given for inquiry; the Irish, in the mean time, howling, and accusing the servant of the school as a murderer and robber. The servant of the school was given into custody by the mayor, and, on being taken to the station-house, was charged, together with fuur bearers, with having carried off the body of Rosanna Rox's mother;-this Rosanna Rox, who was one of the Irish party, having previously stated to the relieving officer and to the medical officer, that she was no relative whatever of the deceased; and the deceased, a short time before her death, having declared to the relieving officer that she had no relatives.

Such is an abridged and unexaggerated account of the affair as it took place, and we leave you to make your own comments thereon. The case was appointed to be heard before the magistrates on the 21st, but was then postponed till the 26th (Saturday.) On this day the woman Rose declared upon oath, that the body in question was that of her mother, and that she died on Thursday night a few minutes before 9 . Now the body was removed just before $40^{\circ}$ 'clock P.s. on Saturday, so that 44 hours, instead of 48 , the time according to the act of Parliament, only had elapsed. In consequence of this informality, the case was reserved for the quarter-sessions on the 6th of January.-We have the honour to remain, gentlemen, your obedient servauts, The Lecturers of the Newcastle on Trae

Nervcastle, Dec. 26, 1840. Medical School.

Through the kindness of the Editor, we have received slips of the " Gateshead Observer," Jan. 2nd, 1841, in which the particulars of the transactions alluded to above, are fully detailed.

"The Medical School received an official intimation of the death of an elderly woman, at the Head of the Side, who had no known relatives; and on Saturday afternoon the janitor of the achool, William Brown, proceeded to the room in which the body lay, and, with the assistance of four carpenters, removed it in a coffin. They were followed by several persons, natives of Ireland, who were much incensed on finding that the body was conveyed to the Medical School, and gave information to the mayor of Newcastle, John Ridley, Esq. His worship, attended by several policemen, and by a large number of other persons, chiefly Irish, proceeded to the Medical School, and demanded admission, which was conceded, and the body, (then lying in warm water, previous to examination) was removed to the house from which it had been brought. The janitor was taken into custody, but was afterwards released on bail.

The chief magistrate, we are informed, was much excited, and conducted himself in a manner not at all culculated to exalt the dignity of his high office. His worship, we think, ought to have paused ere he proceeded on such a mission in person, and especially in a state of excitement. It was his duty-his sacred duty - to lend a ready hearing to the complaining parties, and to institute an immediate investigation into their statement; but this should have been done in a form consistent with his own dignity, and with the respect due to an institution of high character and incalculable worth-an institution conducted by gentlemen of exalted reputation, and whose names afford a guarantee that nothing illegal or dishonourable will knowingly be permitted within its walls. Assuredly, the public authorities of a town should not take a course calculated to deepen a prejudice against so important an establishment as a medical school.

Having made these preliminary statements and remarks, we will now proceed to the investigations of Saturday last. 